\title{
Eksistensi dan Konstruksi Yuridis Badan Usaha Milik Daerah Pasca Undang-Undang Pemerintahan Daerah Tahun 2014
}

\author{
Fauzi Syam, ${ }^{\star}$ Elita Rahmi, ${ }^{\star \star}$ Arsyad ${ }^{\star \star \star}$ \\ ${ }^{\star}$ Fakultas Hukum Universitas Jambi, \\ fauzisyam@unja.ac.id \\ ${ }^{\star \star}$ Fakultas Hukum Universitas Jambi \\ elitarahmi@unja.ac.id \\ ${ }^{\star \star \star}$ Fakultas Hukum Universitas Jambi \\ arsyad@unja.ac.id
}

\begin{abstract}
This article discusses juridical implications about the regulation of stateowned enterprises (BUMD) after the enactment of the Law Number 23 Year 2014 about Regional Government (Regional Government Law 2014) and the application on regulation of BUMD in Jambi Province. Research method in this study is normative juridical with law approach. Based on the results of the study are known, the enactment of Regional Government Law 2014 has implications for the existence and regulations of existing and future of BUMD, namely in terms of form and naming of BUMD; organ of BUMD; tenure of directors and councils; and intervention of DRPD (Regional People's Representative Assembly) on BUMD operations. The result of the study also shows that none of regional governments in Jambi Province have followed up on the mandate of the article 402 paragraph (1) Regional Government Law 2014 to adjust the regulation of BUMD, and that's why it is potentially contradicting with Regional Government Law 2014 and central government policy.
\end{abstract}

Keywords: BUMD; existence and juridical construction; Regional Government Law 


\begin{abstract}
Abstrak
Artikel ini membahas implikasi yuridis pengaturan Badan Usaha Milik Daerah (BUMD) pasca berlakunya Undang-Undang Nomor 23 Tahun 2014 tentang Pemerintahan Daerah (UU Pemda 2014) dan penerapannya pada regulasi BUMD di lingkungan Provinsi Jambi. Metode penelitian yang digunakan adalah yuridis normatif dengan pendekatan perundang-undangan. Berdasarkan hasil kajian diketahui, berlakunya UU Pemda 2014 berimplikasi terhadap eksistensi dan regulasi BUMD baik yang telah ada maupun yang akan dibentuk, yaitu dalam hal bentuk hukum dan penamaan BUMD; persyaratan pendirian dan kelayakan usaha BUMD; penyertaan modal daerah dan kepemilikan modal dalam BUMD; organ BUMD; masa jabatan Direksi dan Dewas/Deris; dan campur tangan DPRD dalam operasional BUMD. Hasil penelitian juga menunjukkan belum ada satu pun Pemda di lingkungan Provinsi Jambi yang menindaklanjuti amanat Pasal 402 ayat (1) UU Pemda 2014 untuk menyesuaikan regulasi BUMD, dan dengan demikian potensial bertentangan dengan UU Pemda 2014 dan kebijakan pemerintah pusat.
\end{abstract}

Kata Kunci: BUMD; eksistensi dan konstruksi yuridis; UU Pemerintahan Daerah

\title{
A. Pendahuluan
}

Artikel ini membahas implikasi yuridis pengaturan Badan Usaha Milik Daerah (BUMD) pasca berlakunya Undang-Undang Nomor 23 Tahun 2014 tentang Pemerintahan Daerah (UU Pemda 2014). Dalam membahas implikasi yuridis tersebut, artikel ini mengambil regulasi BUMD di Provinsi Jambi (meliputi 12 daerah otonom: satu provinsi, dua kota, dan sembilan kabupaten) sebagai bahan kajiannya. Dengan bahasan tersebut akan diketahui apa saja implikasi yuridis dari UU Pemda Tahun 2014 terhadap BUMD terutama terkait dengan eksistensi dan konstruksi yuridisnya, dan bagaimana kesesuaian regulasi BUMD yang ada saat ini dengan yang dikehendaki UU Pemda Tahun 2014.

Keberadaan BUMD dalam penyelenggaraan pemerintahan daerah hingga saat ini masih menimbulkan persoalan, baik dari sisi yuridis maupun tujuan. Dari sisi yuridis, pengaturan tentang BUMD 
pada hakikatnya masih merujuk UU Nomor 5 Tahun 1962 tentang Perusahaan Daerah (UU Perusda) yang secara resmi telah dicabut oleh UU Pemda 2014. ${ }^{1}$ Dari sisi tujuan, banyak BUMD yang didirikan kurang berkontribusi bagi daerah, baik dari sisi nilai tambah pendapatan daerah maupun dampaknya kepada masyarakat. Menurut Arif Afandi, Ketua Badan Kerjasama BUMD Seluruh Indonesia, dari 1.007 jumlah BUMD yang tercatat di Kementerian Dalam Negeri, baru sekitar 20 persen yang menjadi entitas bisnis atau menghasilkan profit. Dari jumlah 20 persen ini, hampir 80 persen didominasi sektor perbankan. ${ }^{2}$ Kondisi ini selaras dengan data Kementerian Dalam Negeri (Kemendagri), bahwa dari 1.123 BUMD di Indonesia pada akhir September 2015 terdapat hanya BUMD perbankan yang tidak merugi dan mampu menghasilkan kontribusi laba. ${ }^{3}$

Apa sebabnya BUMD secara yuridis, ekonomis dan tata kelola masih menghadapi berbagai permasalahan sehingga tidak mampu mencapai tujuan yang diharapkan? Menurut Dirjen Bina Keuangan Daerah Kemendagri, ada empat persoalan mendasar yang dihadapi oleh BUMD di Indonesia, yaitu dasar pengaturan BUMD; prinsip pengelolaan BUMD masih terkontaminasi dengan sistem birokrasi (besarnya campur tangan birokrasi ke dalam BUMD); operasional BUMD yang pada umumnya tidak efisien; dan belum optimalnya BUMD dalam memberikan pelayanan publik. ${ }^{4}$

Berbagai penelitian atau kajian sebelum ini juga menunjukkan permasalahan yang sama. Hasil kajian Setjen DPR RI terhadap pengelolaan BUMD di Provinsi Sumatera Barat, Nusa Tenggara Barat, dan

1 Pasal 409 dengan tegas menyatakan pencabutan dan ketidakberlakuan, antara lain, huruf a: "Undang-Undang Nomor 5 Tahun 1962 tentang Perusahaan Daerah.

2 Lihat Arif Afandi, "Pengelolaan BUMD Harus Profesional", Majalah Kabupaten Report, 5, 1 (2015), hlm. 29. https://www.slideshare.net/ bobbyumbara/majalah-kabupaten-report-52340275

3 Reydonnyzar Moenek, "Problematika, Peluang, Tantangan dan Strategi Pengelolaan BUMD, BLUD dan BMD”, paparan pada Rakernas Revitalisasi BUMD, Pemantapan Penerapan PPK-BLUD, dan Optimalisasi Pengelolaan Barang Milik Daerah, 20/10/2015, http:/keuda.kemendagri.go.id, diakses 15/7/2017.

4 Moenek, "Problematika, Peluang, Tantangan dan Strategi". 
Kalimantan Selatan menemukan permasalahan utama terkait BUMD meliputi pengelolaan yang tidak efisien; pembentukannya yang umumnya tidak didahului studi kelayakan secara terencana; pengendalian dan pengawasan; dan terdapat intervensi birokrasi dan politis yang ada di DPRD (DPRD ikut pula menjadi pengawas dan bahkan menentukan masalah-masalah teknis yang mengganggu pengelolaan BUMD). ${ }^{5}$ Rustian Kamaluddin mengungkapkan permasalahan khusus BUMD, yaitu kurang adanya spesialisasi dan konsentrasi utama dalam bidang usaha BUMD,sehingga efisiensinya rendah dan biaya operasionalnya tinggi, bahkan mengalami kerugian. ${ }^{6}$

Persoalan dasar pengaturan BUMD dalam artikel ini menjadi fokus kajian. Hal ini dilatarbelakangi alasan, pertama, penelitian dan kajian tentang dasar pengaturan BUMD sangat menentukan keberadaan BUMD dalam mencapai tujuannya. UU Perusda sangat tidak lengkap mengatur regulasi BUMD yang mampu membangun BUMD yang sehat dan berperan dalam pengembangan perekonomian daerah, dan karena itu resmi dicabut UU oleh Pemda 2014. Kedua, UU Pemda 2014 (Pasal 402 ayat [2]) mengamanatkan, bahwa paling lama tiga tahun terhitung sejak diundangkan, seluruh regulasi BUMD yang telah ada maupun yang akan diterbitkan, wajib menyesuaikan dengan ketentuan dalam UU Pemda 2014. Kewajiban untuk menyesuaikan regulasi BUMD tersebut akan jatuh tempo pada tanggal 30 September 2017.

Ketiga, Kemendagri pada bulan Juni 2016 telah membatalkan delapan Perda terkait BUMD. ${ }^{7}$ Pembatalan Perda BUMD yang dilaku-

5 Mandala Hareva, "Pengelolaan BUMD/Perusahaan Daerah di Provinsi Sumatera Barat, Nusa Tenggara Barat, dan Kalimantan Selatan”, Jurnal Kajian, 11, 3 (2010), hlm. 16.

6 Rustian Kamaludin, "Peran dan Pemberdayaan BUMD dalam Rangka Peningkatan Ekonomi Daerah”, Majalah Perencanaan Pembangunan, 23 (2001), hlm. 11.

7 Dari 3.143 Perda yang dibatalkan Kemendagri, terdapat 8 Perda terkait BUMD yang turut dibatalkan, baik pembatalan keseluruhan Perda ataupun beberapa pasal atau ayat. Lihat Kemendagri, "Daftar Perda/Perkada dan Peraturan Menteri Dalam Negeri yang Dibatalkan/Direvisi, http://www. kemendagri.go.id/ media/filemanager/2016/06/21/b/a/batal_perda21_ juni_2016.pdf, diakses 20/9/2017. 
kan oleh Kemendagri tersebut membuat isu hukum dalam penelitian ini menjadi urgen dan relevan. Keempat, walaupun beberapa Perda BUMD telah dibatalkan oleh Kemendagri, sebagian besar pemerintah daerah terutama di lingkungan Provinsi Jambi belum melakukan upaya penyesuaian eksistensi dan regulasi BUMD sebagaimana diperintahkan UU Pemda 2014. Bisa jadi hal ini disebabkan Pemda tidak mengetahui atau menyadarinya, atau menganggapnya telah sesuai atau tidak bertentangan, atau justru kesulitan melakukan penyesuaian karena PP tentang BUMD yang baru diterbitkan tahun 2017 setelah melewati batas waktu, yaitu melalui PP Nomor 54 Tahun 2017 tentang BUMD. ${ }^{8}$

Permasalahan hukum dalam penelitian ini relatif belum pernah diteliti sebelumnya. Penelitian Tim Kajian Setjen DPR RI pada tahun 2009 dilakukan berdasarkan UU Pemda 2004, yang dengan begitu jelas berbeda. ${ }^{9}$ Kajian terkait dengan dasar pengaturan BUMD berdasarkan UU Pemda 2014 telah pula dilakukan oleh Made Gde Subha Karma Resen ${ }^{10}$ dan Dhimas Teruko Kesumo dkk., ${ }^{11}$ namun berbeda isu hukumnya terutama dikaitkan dengan eksistensi dan konstruksi BUMD di Provinsi Jambi. Dalam artikel ini, dikaji Perda dan produk hukum daerah yang mengatur BUMD di wilayah Provinsi Jambi. Dari 26 BUMD yang ada, akan dikaji masing-masing 1 Perda dari se-

8 Pada awalnya, dalam beberapa media, Dirjen Keuangan Daerah Kemendagri yang memprakarsai PP tentang BUMD sangat optimis bahwa PP ini akan diterbitkan paling lambat tanggal 1 Oktober 2016 sesuai dengan amanat Pasal 410 UU Pemda 2014.

9 Hasil kajian dipublikasasikan dalam beberapa jurnal. Lihat Hareva, "Pengelolaan BUMD/Perusahaan Daerah"; Ronny Sautma Hotma Bako, "Permasalahan Hukum atas Bentuk Badan Hukum pada Badan Usaha Milik Daerah”, Jurnal Kajian, 15, 4 (2010), hlm. 751-775; Khopiatuziadah, "Landasan Hukum Pengelolaan Badan Usaha Milik Daerah: Antara Ada dan Tiada”, Jurnal Legislasi Indonesia, 11, 3 (2014), hlm. 221-232.

10 Lihat Made Gde Subha Karma Resen, "Implikasi Yuridis Diundangkannya Undang-Undang Nomor 23 Tahun 2014 tentang Pemerintahan Daerah terhadap Pengaturan Badan Usaha Milik Daerah di Indonesia”, Yustisia: Jurnal Hukum, 3, 3 (2014), hlm. 127-135.

11 Dhimas Tetuko Kusumo, Munawar Kholis, dan Sentot Sudarwanto, "Kajian Yuridis Bentuk Hukum Badan Usaha Milik Daerah (BUMD) di Bidang Perbankan Pasca Berlakunya Undang-Undang Nomor 23 Tahun 2014 tentang Pemerintahan Daerah", Jurnal Privat Law, 4, 1 (2016), hlm. 21-29. 
tiap Daerah. ${ }^{12}$

\section{B. Kebutuhan terhadap Eksistensi BUMD (dan BUMN)}

Eksistensi ${ }^{13}$ BUMN dan BUMD dalam sistem perekonomian negara atau daerah, merupakan suatu keniscayaan. Hal ini disebabkan, negara Republik Indonesia menganut negara hukum kesejahteraan (perpaduan konsep negara hukum dan negara kesejahteraan). Kewajiban pemerintah dalam negara kesejahteraan (welfare state) menempatkan tugas utama pemerintah untuk memberikan pelayanan umum atau mengusahakan kesejahteraan bagi warga negaranya, sebagaimana termaktub dalam tujuan bernegara dalam Pembukaan UUD 1945.

Peranan negara melalui BUMN dan BUMD memperoleh legitimasi yang sangat kuat sebagaimana ditegaskan dalam Pasal 33 ayat (2) UUD 1945, "Cabang-cabang produksi yang penting bagi negara dan yang menguasai hajat hidup orang banyak dikuasai oleh negara”. ${ }^{14}$ Secara konstitusional, hal ini diperkuat oleh Mahkamah Konstitusi (MK) melalui Putusan Nomor 62/PUU-XI/ 2013:

Menimbang bahwa berdasarkan ketentuan konstitusional tersebut BUMN, BUMD, atau nama lain yang sejenisnya merupakan bagian dari pelaku dalam sistem perekonomian nasional yang disusun sebagai usaha bersama berdasar atas asas kekeluargaan (vide Pasal 33 ayat [1] UUD 1945). BUMN, BUMD, atau nama lain yang sejenisnya yang berada pada tingkat dan dalam wilayah administrasi yang berbeda mengelola usaha yang objeknya adalah cabang-cabang produksi yang penting bagi negara dan yang menguasai hajat hidup orang banyak atau mengelola usaha yang objeknya bersumber dari bumi dan air dan kekayaan alam yang

12 Pada saat hasil penelitian dilaporkan, PP Nomor 54 Tahun 2017 tentang BUMD belum terbit. Namun secara keseluruhan, substansi PP Nomor 54 Tahun 2017 tidak berbeda secara mendasar dengan substansi dalam UU BUMN dan PP Nomor 45 Tahun 2005 tentang Pendirian, Pengurusan, Pengawasan dan Pembubaran BUMN yang menjadi titik tolak penelitian ini. Oleh sebab itu, hasil penelitian ini masih tetap relevan dan masih tetap dijadikan acuan dengan merujuk pada PP Nomor 54 Tahun 2017.

13 Eksistensi dalam penelitian ini diartikan sebagai keberadaan dan/atau kedudukan yang dihubungkan dengan fungsi dan tujuan pendirian BUMN atau BUMD.

14 Lihat Mahmudin Yasin, "BUMN dan Perekonomian Nasional", https:// www.slideshare.net /pssdm/bumn-dan-pembangunan-nasional-12-des2013-finalnon-lam-piran, diakses 10/9/2017. 
terkandung di dalamnya. Kedua macam objek tersebut, sesuai dengan cita sistem perekonomian yang dikehendaki ketika membentuk negara, dikuasai oleh negara dan dipergunakan untuk sebesar-besar kemakmuran rakyat (vide Pasal 33 ayat [2] dan ayat [3] UUD 1945). Dengan demikian maka usaha terhadap kedua objek tersebut, yang menjadi fungsi BUMN, BUMD, atau nama lain yang sejenisnya, merupakan derivasi dari penguasaan negara atas kedua objek tersebut sebagai bagian dari fungsi negara. Itulah pengertian yang lebih teknis dari BUMN, BUMD, atau nama lain yang sejenisnya sebagai kepanjangan tangan negara. ${ }^{15}$

Berdasarkan pertimbangan Putusan MK tersebut, maka argumentasi dasar yang dibangun dalam penelitian ini adalah, pertama, BUMN dan BUMD pada hakikatnya mempunyai kedudukan yang sama yaitu perusahaan yang didirikan oleh negara dan daerah yang seluruh atau sebagian besar sahamnya merupakan milik negara atau milik daerah yang merupakan kepanjangan tangan negara atau daerah yang bersumber dari ketentuan Konstitusi Pasal 33. Sebagai kepenjangan tangan negara, BUMN dan BUMD merupakan bagian dari pelaku dalam sistem perekonomian nasional.

Kedua, BUMN dan BUMD pada hakikatnya mempunyai tujuan yang sama, yaitu menjalankan fungsi pelayanan publik (public services) dengan menyelenggarakan usaha yang "bertujuan untuk kemanfaatan umum", ${ }^{16}$ berupa penyediaan barang dan/atau jasa yang berkualitas dengan harga yang terjangkau oleh masyarakat berdasarkan prinisip pengelolaan perusahaan yang sehat; serta "mengejar keuntungan" (fungsi profitasi) atau "memperoleh laba dan/atau keuntungan"17 yang dimanfaatkan bagi perkembangan perekonomian nasional dan daerah.

Ketiga, secara normatif, perbedaan antara BUMN dan BUMD tidak bersifat prinsipil. Menurut Mandala Hareva, perbedaan utama

15 Putusan MK Nomor 62/PUU-XI/2013, dalam perkara Pengujian UndangUndang Nomor 17 Tahun 2003 tentang Keuangan Negara dan UndangUndang Nomor 15 Tahun 2006 tentang Badan Pemeriksa Keuangan terhadap Undang-Undang Dasar Negara Republik Indonesia Tahun 1945, hlm. 228.

16 Lihat Pasal 36 ayat (1) UU BUMN dan Pasal 331 ayat (4) huruf b UU Pemda 2014.

17 Lihat Pasal 12 huruf b UU BUM dan Pasal 331 ayat (4) huruf c UU Pemda 2014 
antara BUMN dengan BUMD hanya pada skala kegiatan usaha dan jangkauan pelayanan barang dan jasa bagi masyarakatnya, ${ }^{18}$ atau seperti dikatakan MK hanyalah pada tingkat dan dalam wilayah administrasi yang berbeda. ${ }^{19}$ BUMD skalanya lebih bersifat lokal sementara BUMN bersifat nasional.

Keempat, karena kedudukan dan fungsi BUMN dan BUMD pada hakikatnya adalah sama, maka prinsip-prinsip pengaturan tata kelola perusahaan yang baik yang terdapat dalam UU BUMN (UU Nomor 19 Tahun 2003) dan peraturan pelaksananya dapat diberlakukan terhadap prinsip-prinsip pengaturan dalam BUMD, sepanjang tidak diatur secara khusus dalam UU Pemda 2014. Dengan demikian, kriteria pengujian yang digunakan dalam penelitian ini, sepanjang tidak diatur dalam UU Pemda 2014 dan PP Nomor 54 Tahun 2017, akan menggunakan prinsip-prinsip yang dimuat dalam UU BUMN dan peraturan pelaksananya.

\section{BUMD di Provinsi Jambi}

Provinsi Jambi terdiri dari dua Kota dan sembilan Kabupaten. Setiap Daerah, telah memiliki BUMD. Secara keseluruhan, jumlah BUMD yang ada di Provinsi Jambi sebanyak 26 BUMD. Dilihat dari sudut bentuk hukum, terdapat 19 BUMD Perumda (Perusda) dan tujuh BUMD Perseroda (PT). Dilihat dari sudut lapangan usaha, maka dapat dibedakan atas tiga kelompok, yaitu BUMD yang bergerak di bidang pelayanan air minum, BUMD yang bergerak di bidang perbankan, dan BUMD yang bergerak di bidang aneka usaha. Profil BUMD di Provinsi Jambi tersebut, disajikan pada Tabel 1.

Beberapa catatan terkait data pada tabel tersebut adalah, pertama, setiap daerah pada umumnya memiliki BUMD Air Minum, kecuali Provinsi Jambi dan Kota Sungai Penuh. Kedua, pendirian BUMD Air Minum pada umumnya didirikan pada masa berlakunya UU Pemda 1974, kecuali pada daerah pemekaran (Tebo, Muaro Jambi, dan Sarolangun) yang didirikan pada masa berlakunya UU

18 Hareva, "Pengelolaan BUMD/Perusahaan Daerah", hlm. 7.

19 Putusan MK Nomor 62/PUU-XI/ 2013. 
Tabel 1: BUMD di Provinsi Jambi Dilihat dari Lapangan Usaha dan Tahun Pendirian

\begin{tabular}{|c|c|c|c|c|c|c|c|c|c|}
\hline \multirow[b]{2}{*}{ No } & \multirow[b]{2}{*}{ Daerah } & \multicolumn{4}{|c|}{ Lapangan Usaha } & \multicolumn{4}{|c|}{ Tahun Pendirian (UU Pemda) } \\
\hline & & $\begin{array}{c}\text { Air } \\
\text { Minum }\end{array}$ & Perbankan & $\begin{array}{l}\text { Aneka } \\
\text { Usaha }\end{array}$ & $\mathrm{Jml}$ & $\begin{array}{l}\text { UU } \\
5 / 74\end{array}$ & $\begin{array}{c}\text { UU } \\
22 / 99\end{array}$ & $\begin{array}{c}\text { UU } \\
32 / 04\end{array}$ & $\begin{array}{c}\text { UU } \\
23 / 14\end{array}$ \\
\hline 1 & Prov Jambi & 0 & 1 & 1 & 2 & 1 & 1 & 0 & 0 \\
\hline 2 & Kota Jambi & 1 & 0 & 0 & 1 & 1 & 0 & 0 & 0 \\
\hline 3 & Kab Muaro Jambi & 1 & 0 & 1 & 2 & 0 & 2 & 0 & 0 \\
\hline 4 & Kab Batanh Hari & 1 & 0 & 1 & 2 & 1 & 0 & 1 & 0 \\
\hline 5 & Kab Tanjabar & 1 & 1 & 1 & 3 & 2 & 1 & 0 & 0 \\
\hline 6 & Kab Tanjabtim & 1 & 1 & 2 & 4 & 0 & 3 & 1 & 0 \\
\hline 7 & Kab Merangin & 1 & 0 & 1 & 2 & 1 & 0 & 0 & 1 \\
\hline 8 & Kab Sarolangun & 1 & 0 & 1 & 2 & 0 & 2 & 0 & 0 \\
\hline 9 & Kab Bungo & 1 & 0 & 1 & 2 & 1 & 1 & 0 & 0 \\
\hline 10 & Kab Tebo & 1 & 0 & 1 & 2 & 0 & 2 & 0 & 0 \\
\hline 11 & Kab Kerinci & 1 & 0 & 2 & 3 & 1 & 2 & 0 & 0 \\
\hline 12 & Kota Sei Penuh & 0 & 0 & 1 & 1 & 0 & 0 & 1 & 0 \\
\hline & Jumlah & 10 & 3 & 13 & 26 & 8 & 14 & 3 & 1 \\
\hline & Persentase & 38,5 & 11,5 & 50 & 100 & 30,7 & 53,8 & 11,5 & 4 \\
\hline
\end{tabular}

Pemda 1999. Ketiga, sebagian besar BUMD bergerak di bidang aneka usaha (50\%), dan rata-rata bergerak pada 12 bidang usaha. Keempat, sebagian besar BUMD (53,8\%) didirikan pada masa berlakunya UU Pemda 2009. Pada masa UU Pemda 2014, hanya 1 BUMD yang didirikan.

Tabel 2: Jumlah Objek Evaluasi Perda BUMD

\begin{tabular}{|c|c|c|c|c|c|c|c|}
\hline \multirow[t]{2}{*}{$\begin{array}{l}\mathrm{N} \\
\mathrm{O}\end{array}$} & \multirow[t]{2}{*}{ Daerah } & \multicolumn{3}{|c|}{$\begin{array}{l}\text { Jumlah } \\
\text { BUMD }\end{array}$} & \multicolumn{3}{|c|}{ Objek Evaluasi } \\
\hline & & PD & PT & Jml & $\begin{array}{c}\text { Perda } \\
\text { No }\end{array}$ & Nama BUMD & $\begin{array}{c}\text { Jml Bid } \\
\text { Usaha }\end{array}$ \\
\hline 1 & Kota Jambi & 1 & 0 & 1 & $7 / 1974$ & $\begin{array}{l}\text { PDAM Tirta Mayang Kota } \\
\text { Jambi }\end{array}$ & 1 \\
\hline 2 & Kab. B.hari & 2 & 0 & 2 & $2 / 2008$ & PD Batanghari Sejahtera & 1 \\
\hline 3 & Kab. M.Jambi & 2 & 0 & 2 & $36 / 2003$ & PD Muaro Jambi & 12 \\
\hline 4 & Kab. Tebo & 2 & 0 & 2 & $13 / 2001$ & PD Tebo Holding Company & 14 \\
\hline 5 & Kab. Tanjabbar & 3 & 0 & 3 & $7 / 2002$ & $\begin{array}{l}\text { PD Jabung Barat Sakti Holding } \\
\text { Company }\end{array}$ & 11 \\
\hline 6 & Kab. Kerinci & 2 & 1 & 3 & $2 / 2003$ & $\begin{array}{l}\text { PD Kerinci Holding Sakti } \\
\text { Investama }\end{array}$ & 14 \\
\hline 7 & Kab. Sarolangun & 2 & 0 & 2 & $14 / 2001$ & PD Serumpun Pseko & 11 \\
\hline 8 & Provinsi Jambi & 0 & 2 & 2 & $13 / 2001$ & $\begin{array}{l}\text { PT. Jambi Indoguna } \\
\text { Internasional }\end{array}$ & 11 \\
\hline 9 & Kab. Tanjabtim & 3 & 1 & 4 & $9 / 2013$ & PT. Sabak Holding Company & 12 \\
\hline 10 & Kab. Bungo & 1 & 1 & 2 & $3 / 2001$ & PT. Bungo Dani Mandiri Utama & 20 \\
\hline 11 & $\begin{array}{l}\text { Kota Sungai } \\
\text { Penuh }\end{array}$ & 0 & 1 & 1 & $3 / 2013$ & PT. Mapan Kota Sungai Penuh & 5 \\
\hline 12 & Kab. Merangin & 1 & 1 & 2 & $6 / 2015$ & $\begin{array}{l}\text { Pembentukan BUMD (tidak } \\
\text { bernama) }\end{array}$ & 8 \\
\hline
\end{tabular}


Dari 26 BUMD yang ada di Provinsi Jambi, dikaji masing-masing satu Perda BUMD yang dimiliki Provinsi, Kabupaten dan Kota sebagaimana disajikan pada Tabel 2.

\section{Implikasi Yuridis Pengaturan BUMD Pasca Berlakunya UU Pemda 2014 dan PP Nomor 54 Tahun 2017}

\section{Implikasi Terhadap Bentuk Hukum dan Penamaan BUMD}

Berbeda dengan UU Perusda, UU Pemda 2014 (Pasal 331 ayat 3) membedakan bentuk hukum BUMD atas dua bentuk, yaitu Perusahaan Umum Daerah (Perumda) dan Perusahaan Perseroan Daerah (Persorada). Hal ini bisa menimbulkan pertanyaan, bagaimana caranya Pemerintah Daerah harus memilih atau memutuskan membentuk BUMD Perumda atau BUMD Perseroda?

Mengacu kepada UU BUMN dan PP Nomor 45 Tahun 2005, pembedaan antara BUMN Perum dan BUMN Persero tergantung pada tujuan dan sifat usahanya. BUMN Perum tujuan usahanya lebih pada pelayanan demi kemanfaatan umum (public service obligation), baik pelayanan maupun penyediaan barang dan jasa. Namun demikian, sebagai badan usaha, diupayakan untuk tetap mandiri dan untuk itu Perum perlu mendapat laba agar dapat hidup berkelanjutan, ${ }^{20}$ sehingga dapat menutup biaya operasional. Perum menyelenggarakan usaha yang bertujuan untuk kemanfaatan umum berupa penyedia barang dan jasa yang berkualitas dengan harga yang terjangkau berdasarkan prinsip pengelolaan perusahaan yang sehat. ${ }^{21}$ Menurut Christine S.T Kansil, tujuan perusahaan umum bergerak dalam bidang-bidang jasa vital atau public utilites. ${ }^{22}$ Menurut Kamus Besar Bahasa Indonesia, vital dapat diartikan sangat penting (kehidupan orang) atau menyangkut hajat orang banyak. ${ }^{23}$ Vital artinya sangat

20 Lihat Pasal 36 UU BUMN dan Penjelasannya.

21 Mulhadi, Hukum Perusahaan, Bentuk-Bentuk Badan Usaha di Indonesia (Bogor: Ghalia Indonesia, 2010), hlm. 177.

22 Christine S.T. Kansil, Hukum Perusahaan Indonesia (Aspek Hukum Dalam Ekonomi) (Jakarta: Pradnya Paramita, 2010), hlm. 57-58.

23 http://kbbi.web.id/vital, diakses 8/7/2017 
penting dan fungsinya tidak bisa digantikan oleh organ lain. Logika vital jika dianalogikan dalam konsep hukum perusahaan adalah jenis usaha tersebut bersifat sangat strategis yang tidak boleh diserahkan ke swasta karena menyangkut hajat orang banyak dan bersifat monopolistik. ${ }^{24}$

Berbeda dengan tujuan khusus BUMN Perum, tujuan khusus BUMN Persero adalah mengejar keuntungan guna meningkatkan nilai perusahaan dengan sifat usaha menyediakan barang dan/atau jasa yang bermutu tinggi dan berdaya saing kuat baik di pasar dalam negeri maupun internasional. Dengan demikian, dapat meningkatkan keuntungan dan nilai Persero yang bersangkutan sehingga akan memberikan manfaat yang optimal bagi pihak-pihak terkait. ${ }^{25}$ Berdasarkan tujuan khusus tersebut, BUMN Persero dalam operasionalnya tunduk pada UU Nomor 40 Tahun 2007 tentang Perseroan Terbatas (UU PT).

Berbeda dengan UU BUMN yang telah diuraikan di atas, Pasal 331 ayat (4) UU Pemda 2014 hanya mengatur secara umum tujuan pendirian BUMD, yaitu untuk: (a) memberikan manfaat bagi perkembangan perekonomian daerah pada umumnya; (b) menyelenggarakan kemanfaatan umum berupa penyediaan barang dan/ atau jasa yang bermutu bagi pemenuhan hajat hidup masyarakat sesuai kondisi, karakteristik dan potensi daerah yang bersangkutan berdasarkan tata kelola perusahaan yang baik; dan (c) memperoleh laba dan/atau keuntungan.

Mencermati bentuk hukum BUMD dan tujuan pendirian BUMD dalam UU Pemda 2014 tersebut, belum tampak pembedaan tujuan khusus yang membedakan karakteristik Perumda dan Perseroda. Pertanyaan hukum yang muncul adalah, apakah tujuan Perumda dan Perseroda seyogyanya sama atau perlu dibedakan? Jika perlu dibedakan, bagaimanakah menentukan tujuan yang bersifat khusus antara Perumda dan Perseroda? Menurut penulis, perlu dibedakan tujuan khusus pendirian Perumda dengan Perseroda, dengan

24 Kusumo, Kholis, dan Sudarwanto, "Kajian Yuridis Bentuk Hukum BUMD”, hlm. 27.

25 Lihat Penjelasan Pasal 12 UU BUMN. 
alasan: pertama, bertolak dari teori logika hukum, jika tujuan pendirian Perumda dengan tujuan pendirian Perseroda adalah sama, maka pembentuk undang-undang tidak perlu membedakan dua bentuk BUMD (Perumda dan Perseroda). Cukup digunakan bentuk hukum tunggal "Perusahaan Daerah" sebagaimana digunakan oleh UU Perusda. Kedua, dari sisi karakteristik, ada perbedaan antara Perumda dan Perseroda, baik dari sisi dasar hukum pendirian, kepemilikan perusahaan, dan organ perusahaan (akan dijelaskan di bawah). Ketiga, mencegah kekeliruan hukum pada masa lalu. Pada saat Permendagri Nomor 3 Tahun 1998 tentang Bentuk Hukum BUMD diberlakukan, tidak dijelaskan karakteristik antara BUMD Perusda dan BUMD Perseroan Terbatas. Dalam peraturan ini hanya disebutkan jika BUMD berbentuk Perusda tunduk pada peraturan perundang-undangan yang berlaku yang mengatur perusahaan daerah, sedangkan BUMD berbentuk Perseroan Terbatas tunduk pada UU Perseroan Terbatas dan peraturan pelaksanaannya (Pasal 3). Karena ketidakjelasan kedua karakteristik tersebut, maka dalam praktik banyak BUMD yang seharusnya berbentuk Perseroan Terbatas, tetapi bentuk hukumnya "Perusda". Demikian pula sebaliknya, seharusnya berbentuk "Perseroan Terbatas", tetapi bentuk hukumnya Perusda.

Dengan terbitnya PP Nomor 54 Tahun 2017, telah dibedakan tujuan umum dan tujuan khusus pendirian BUMD. Menurut Pasal 8 dan Penjelasannya, pendirian BUMD Perumda diprioritaskan dalam rangka menyelenggarakan kemanfaatan umum berupa penyediaan barang dan/atau jasa yang bermutu tinggi bagi pemenuhan hajat hidup masyarakat sesuai kondisi, karakteristik dan potensi daerah yang bersangkutan berdasarkan tata kelola perusahaan yang baik. Apa yang dimaksud dengan "penyediaan kemanfaatan umum" antara lain:

a. Usaha perintisan berupa penyediaan barang dan/atau jasa yang bermutu dan terjangkau oleh masyarakat; dan

b. Usaha penyediaan pelayaan air minum yang lebih efisien jika dibandingkan dengan penyediaan oleh perangkat daerah.

Sementara tujuan khusus Perseroda bertujuan (titik berat) memupuk keuntungan dan sepenuhnya tunduk pada ketentuan UU PT 
sehingga dapat memberikan manfaat bagi perekonomian daerah pada umumnya. ${ }^{26}$

Implikasi dari bentuk hukum BUMD tersebut di atas, maka penamaan BUMD pasca berlakunya UU Pemda 2014 juga seharusnya berubah. Namun demikian, UU Pemda 2014 tidak memberikan petunjuk bagaimana seharusnya penamaan BUMD tersebut. Ketentuan soal penamaan ini baru diatur dalam PP Nomor 54 Tahun 2007 (Pasal 12 ayat [3] dan Pasal 14 ayat [4]) yang menyebutkan:

1. Nama Perusahaan Umum Daerah didahului dengan perkataan Perusahaan Umum Daerah atau disingkat dengan Perumda yang dicantumkan sebelum nama perusahaan.

2. Dalam hal penulisan nama Perusahaan Perseroan Daerah dilakukan secara lengkap didahului dengan perkataan Perusahaan Perseroan Daerah diikuti dengan nama perusahaan.

3. Dalam hal penulisan nama Perusahaan Perseroan Daerah dilakukan secara singkat, kata (Perseroda) dicantumkan setelah singkatan PT dan nama perusahaan. ${ }^{27}$

Bertolak dari tujuan umum dan khusus Perumda dan Perseroda serta penamaan BUMD, maka prinsip hukum hukum terhadap bentuk hukum dan penamaan BUMD adalah:

1. Semua BUMD di bidang air minum yang berbentuk "Perusda" eksistensinya tetap dipertahankan, namun penamaannya berubah yang didahului dengan sebutan "Perusahaan Umum Daerah (Perumda)". Hal ini disebabkan, pengelolaan air minum berdasarkan putusan Mahkamah Konstitusi "merupakan kelanjutan hak menguasai oleh negara dan karena air merupakan sesuatu yang

26 Tujuan khusus Perseroda mengacu kepada tujuan khusus Persero. Lihat Penjelasan Pasal 12 UU BUMN.

27 Pasca berlakunya PP Nomor 54/2017, masih terdapat kekeliruan soal penamaan BUMD ini. Sebagai contoh Perda Provinsi Kalimantan Timur Nomor 9/2018 tentang Perubahan Atas Perda Nomor 11 Tahun 2009 tentang Perseroan Terbatas (PT) Migas Mandiri Pratama Kalimantan Timur. Dalam Pasal 2 ayat (1) disebutkan: "Dengan Peraturan Daerah ini didirikan BUMD dalam bentuk Perseroan Terbatas (PT) Migas Mandiri Pratama Kalimantan Timur (Perseroda)". Seharusnya penamaan yang tepat adalah: "Dengan Peraturan Daerah ini didirikan Perusahaan Perseroan Daerah (Perseroda) PT Migas Mandiri Pratama Kalimantan Timur.” 
sangat menguasai hajat hidup orang banyak maka prioritas utama yang diberikan pengusahaan atas air adalah BUMN atau BUMD”. ${ }^{28}$ Bentuk hukum BUMD yang paling tepat untuk mengelola hajat hidup orang banyak (public service obligation) adalah BUMD Perumda, sebagaimana dimaksud dalam Pasal 8 PP Nomor 54 Tahun 2017.

2. Semua BUMD yang berbentuk Perseroan Terbatas, eksistensinya tetap dapat dipertahankan, namun penamaannya berubah yang didahului dengan sebutan "Perseroan Daerah (Perseroda)".

3. Semua BUMD yang berbentuk "Perusahaan Daerah" namun karakteristiknya bertujuan untuk memperoleh laba dan/atau keuntungan, maka bentuk hukumnya berubah menjadi Perseroda.

Tabel 3: Review Kesesuaian Bentuk Hukum dan Penamaan BUMD di Provinsi Jambi Dilihat dari Sisi Tujuan BUMD Berdasarkan UU Pemda 2014

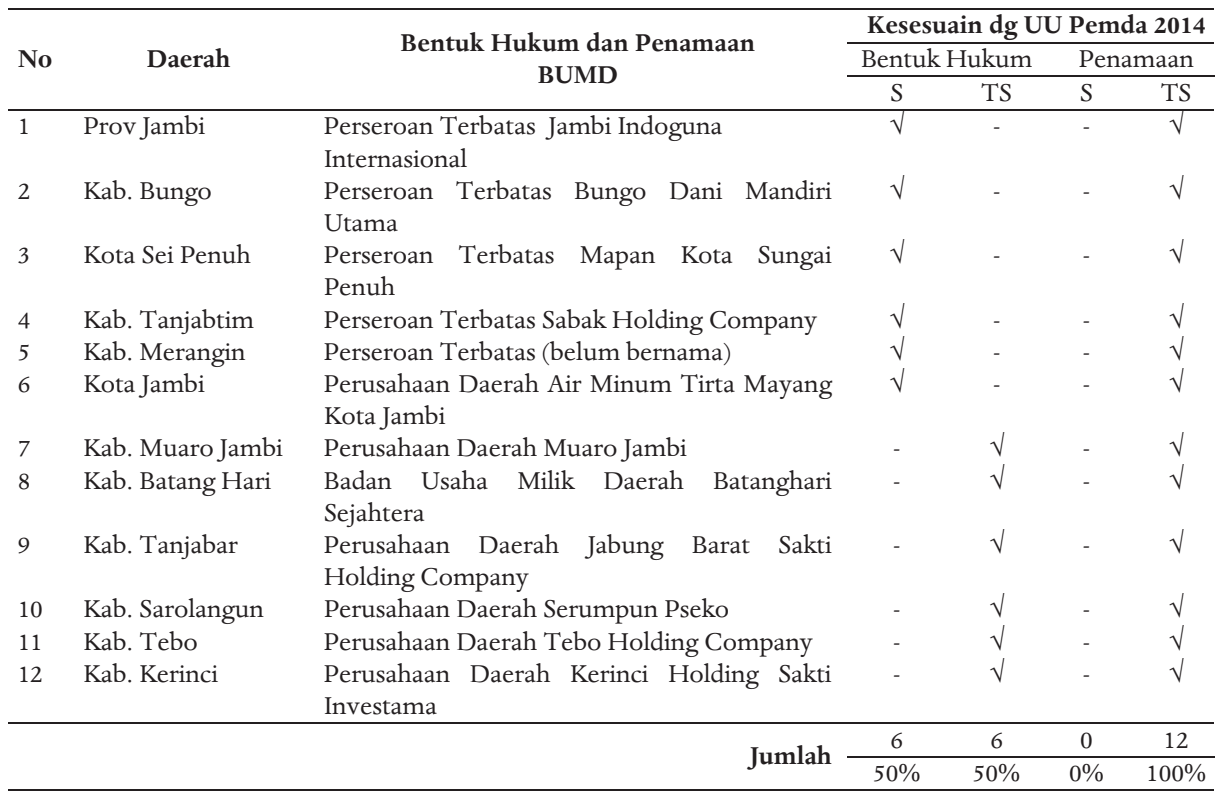

Bagaimanakah implikasi bentuk hukum dan penamaan BUMD pasca berlakunya UU Pemda 2014 dan PP Nomor 54 Tahun 2017 apa-

28 Lihat Putusan MK Nomor 62/PUU-XI/ 2013. 
bila dihubungkan dengan bentuk hukum dan penamaan BUMD di Provinsi Jambi? Dengan menganalisis objek Perda BUMD yang dievaluasi, diketahui bentuk hukum dan penamaan BUMD hasilnya ditunjukkan pada Tabel 3.

Berdasarkan Tabel 3, tampak bahwa 50 persen (6 Perda BUMD) yang bentuk hukumnya sesuai dengan UU Pemda 2014, sedangkan selebihnya tidak sesuai. Ketidaksesuain bentuk hukum tersebut disebabkan oleh, pertama, bidang usaha BUMD tidak sesuai dengan karakteristik Perumda yaitu menyelenggarakan usaha untuk kemanfaatan umum (public services), misalnya pengelolaan sumber daya sumur tua potensial yang menjadi lapangan usaha BUMD Batanghari Sejahtera, tidak termasuk lingkup menyelenggarakan usaha kemanfaatan umum pelayanan jasa umum (public services). Kedua, tujuan pendiriannya menitikberatkan pada tujuan untuk memperoleh laba / keuntungan dalam rangka peningkatan Pendapatan Asli Daerah.

Berbeda dengan bentuk hukum BUMD, dari sisi penamaan, seluruh BUMD yang ada tidak sesuai dengan UU Pemda 2014. Dengan asumsi bahwa keberadaannya tetap dipertahankan, maka penamaan BUMD tampak dalam Tabel 4.

Tabel 4: Contoh Bentuk Hukum dan Penamaan BUMD di Provinsi Jambi Pasca Berlakunya UU Pemda 2014

\begin{tabular}{lcll}
\hline No & Daerah & \multicolumn{1}{c}{ Nama dan Singkatan BUMD } & \multicolumn{1}{c}{$\begin{array}{c}\text { Nama dan Singkatan BUMD } \\
\text { (Pasca UU Pemda 2014) }\end{array}$} \\
\hline 1 & Provinsi Jambi & $\begin{array}{l}\text { Perseroan Terbatas Jambi } \\
\text { Indoguna Internasional }\end{array}$ & $\begin{array}{l}\text { Perseroan Daerah (Perseroda) PT Jambi } \\
\text { Indoguna Internasional }\end{array}$ \\
& & PT. JII & PT JII (Perseroda) \\
\multirow{2}{*}{ Kota Jambi } & Perusahaan Daerah Air Minum & Perusahaan Umum Daerah (Perumda) \\
& & Tirta Mayang Kota Jambi & Air Minum Tirta Mayang Kota Jambi \\
& & PDAM Tirta Mayang Kota Jambi & Perumda Tirta Mayang Kota Jambi \\
\hline
\end{tabular}

\section{Implikasi terhadap Persyaratan Pendirian BUMD}

Berbeda dengan UU Perusda, UU Pemda 2014 (Pasal 331 ayat 5) dan Pasal 9 PP Nomor 54 Tahun 2017 mensyaratkan pendirian BUMD harus melalui studi kelayakan (naskah akademik) yang didasarkan pada kebutuhan daerah dan kelayakan bidang usaha usaha BUMD yang akan dibentuk. Kebutuhan daerah dikaji melalui studi yang 
mencakup aspek pelayanan umum dan kebutuhan masyarakat, dan merupakan bagian dari kebijakan RPJMD. Kelayakan bidang usaha dikaji melalui analisis terhadap kelayakan ekonomi, analisis pasar dan pemasaran, dan analisis kelayakan keuangan serta analisis aspek lainnya (aspek peraturan perundang-undangan, ketersediaan teknologi, dan ketersediaan SDM). Kelayakan usaha akan menghasilkan bisnis utama (core business) dari BUMD yang dibentuk.

Berdasarkan studi kelayakan tersebut, kepala daerah menyampaikan usulan rencana pendirian BUMD kepada Menteri Dalam Negeri (Mendagri). Usulan rencana pendirian BUMD tersebut dilampiri dengan hasil studi kelayakan yang menjelaskan: (a) kebutuhan daerah; (b) analisa kelayakan usaha; (c) ringkasan laporan keuangan pemerintah daerah 3 tahun terakhir; (d) dokumen perda tentang APBD 3 tahun terakhir, dan (e) dokumen RPJMD. Hasil penilaian menteri (layak atau tidak layak), disampaikan kepada gubernur atau bupati/walikota paling lambat 15 hari kerja. Berdasarkan hasil penilaian menteri, barulah daerah dapat menyusun rancangan perda yang mengatur pendirian BUMD. ${ }^{29}$

Pertanyaannya kemudian, apakah mekanisme studi kelayakan dan pengusulan pendirian BUMD yang diatur dalam Pasal 10 dan Pasal 11 PP Nomor 54 Tahun 2017 hanya berlaku bagi pendirian BUMD yang baru? Bagaimana halnya dengan perubahan bentuk hukum BUMD atau pembentukan BUMD baru sebagai akibat peleburan BUMD Perumda dan Perseroda? Apakah dalam studi kelayakan tersebut juga harus dilampiri dengan rancangan Perda BUMD? Menurut penulis, mekanisme studi kelayakan dan pengusulan pendirian BUMD sebagaimana diatur dalam Pasal 10 dan Pasal 11 berlaku untuk pendirian BUMD baru, perubahan bentuk hukum BUMD atau pembentukan BUMD baru sebagai akibat peleburan BUMD Perumda dan Perseroda. Hal ini disebabkan, pertama, perubahan bentuk hukum BUMD dari BUMD Perumda menjadi BUMD Perseroda maupun peleburan BUMD pada hakikatnya merupakan pembentukan BUMD baru, karena terjadi perubahan yang cukup

29 Lihat Pasal 10 PP Nomor 54/2017. 
mendasar dalam pengelolaannya. Oleh sebab itu, dalam Pasal 4 ayat (1) PP Nomor 44 Tahun 2005 disebutkan, lingkup pendirian BUMN meliputi: (a) pembentukan Perum atau Persero baru; (b) perubahan bentuk unit instansi pemerintah menjadi BUMN; (c) perubahan bentuk badan hukum BUMN; atau (d) pembentukan BUMN sebagai akibat dari peleburan Persero dan Perum. Kedua, perubahan bentuk hukum BUMD maupun peleburan BUMD tetap harus dilampiri dengan studi kelayakan. Studi kelayakanakan menghasilkan bisnis utama (core business) BUMD, besaran Penyertaan Modal Daerah (PMD) ke dalam BUMD, dan kompetensi SDM yang dibutuhkan untuk menjalankan BUMD, baik sebagai direksi maupun dewan pengawas / dewan komisaris. Keharusan adanya studi kelayakan, karena karakteristik BUMD berbeda dengan perusahaan swasta. BUMD hadir dalam rangka mendukung pencapaian tugas-tugas pemerintahan, pelayanan kepada masyarakat, yang memang membutuhkan peran Pemerintah Daerah. Dengan kata lain, BUMD tidak boleh didirikan apabila dianggap lapangan usaha tersebut sudah selayaknya dilakukan oleh swasta. Ketiga, berbagai hasil kajian dan penelitian menunjukkan bahwa kegagalan BUMD selama ini berkaitan dengan tidak adanya studi kelayakan terkait bisnis utama (core business), atau menurut Rustian Kamaluddin, "kurang adanya spesialisasi dan konsentrasi utama dalam bidang usaha BUMD”, yang menyebabkan efisiensi rendah dan biaya operasional tinggi yang berdampak pada beban utang dan biaya operasional yang tinggi sehingga laba usaha relatif rendah atau bahkan mengalami kerugian. ${ }^{30}$

Berdasarkan ketentuan tersebut di atas, maka prinsip persyaratan pendirian BUMD $^{31}$ pasca berlakunya UU Pemda 2014 adalah:

1. Pendirian BUMD baik dalam rangka pendirian BUMD baru, perubahan bentuk hukum BUMD, maupun pembentukan BUMD baru sebagai akibat peleburan BUMD Perumda dan Perseroda,

30 Kamaludin, "Peran dan Pemberdayaan BUMD”.

31 Merujuk pada UU BUMN dan Pasal 4 ayat (1) PP Nomor 44/2005, termasuk dalam lingkup "Pendirian BUMD” adalah: (a) pendirian BUMD baru; (b) perubahan bentuk hukum BUMD (c) pembentukan BUMD baru sebagai akibat peleburan BUMD Perumda dan Perseroda. 
wajib melalui studi kelayakan terlebih dahulu.

2. Konsekuensi dari studi kelayakan, maka dalam pendirian BUMD, harus ada bisnis utama (core business) dari lapangan usaha BUMD yang didirikan. Keharusan adanya bisnis utama tersebut berhubungan dengan berapa besaran Penyertaan Modal Daerah (PMD) ke dalam BUMD, kompetensi SDM direksi dan dewas/ deris yang dibutuhkan untuk menjalankan BUMD agar direksi fokus menjalankan mandat yang diberikan, serta memudahkan pembinaan BUMD oleh pemda.

3. Berdasarkan studi kelayakan tersebut, kepala daerah menyampaikan usulan rencana pendirian BUMD kepada Mendagri. Usulan tersebut dilampiri dengan hasil studi kelayakan yang menjelaskan: (a) kebutuhan daerah; (b) analisa kelayakan usaha; (c) ringkasan laporan keuangan pemerintah daerah 3 tahun terakhir; (d) dokumen Perda tentang APBD 3 tahun terakhir, (e) dokumen RPJMD; dan (f) rancangan Perda BUMD. Berdasarkan hasil penilaian menteri, barulah daerah dapat menyusun rancangan Perda yang mengatur pendirian BUMD.

Bagaimanakah implikasi berlakunya UU Pemda 2014 bila dihubungkan dengan persyaratan pendirian BUMD di Provinsi Jambi? Dengan menganalisis Perda BUMD yang dievaluasi, lapangan usaha BUMD hasilnya ditunjukkan pada Tabel 5.

Tabel 5 menunjukkan bahwa rata-rata lapangan usaha pada 10 BUMD luas dan tidak terbatas yaitu mencakup 10 bidang. Hal ini tidak sesuai dengan Pasal 335 ayat (1) UU Pemda 2014 yang mensyaratkan BUMD harus memiliki bisnis utama (core business). Apalagi dengan adanya klausul "usaha lainnya", maka bidang usaha BUMD sesungguhnya menjadi tidak ada batas. Sebagai contoh PT JII (BUMD Provinsi Jambi), berkiprah sebagai distributor semen. ${ }^{32}$ Lebih lanjut,

32 Menurut BPK RI, Kabupaten Batang Hari hanya mempunyai satu BUMD yaitu PDAM Tirta Batanghari yang dibentuk melalui Perda Kabupaten Batang Hari Nomor 12/1990. Periksa Laporan Hasil Pemeriksaan BPK Atas Efektifitas Tata Kelola Pemerintah Daerah Dalam Pembinaan BUMD TA 2011-2016 pada Pemerintah Kabupaten Batanghari, Nomor 38/LHP/ XVIII.JMB/11/2016, hlm. 43. Dengan demikian, BUMD Batanghari sejak didirikan tidak operasional. Namun Perda pendirian BUMD tersebut tidak 
Tabel 5: Bidang Usaha BUMD di Provinsi Jambi

\begin{tabular}{|c|c|c|c|c|c|c|c|c|c|c|c|c|c|c|}
\hline \multirow{2}{*}{ No } & \multirow{2}{*}{\multicolumn{2}{|c|}{ Bidang Usaha BUMD Perusda }} & \multicolumn{12}{|c|}{ BUMD } \\
\hline & & & $\mathrm{PJ}$ & BG & SP & TT & MR & $\mathrm{KJ}$ & MJ & TB & $\mathrm{BH}$ & SR & TBo & $\mathrm{KR}$ \\
\hline 1 & \multicolumn{2}{|l|}{ Air Minum } & & - & - & - & - & $\sqrt{ }$ & - & - & - & - & - & - \\
\hline 2 & \multicolumn{2}{|c|}{ Industri (pengolah airkemasan) } & $\sqrt{ }$ & - & $\sqrt{ }$ & $\sqrt{ }$ & - & - & $\sqrt{ }$ & $\sqrt{ }$ & - & - & $\sqrt{ }$ & $\sqrt{ }$ \\
\hline 3 & \multicolumn{2}{|c|}{ Kelistrikan } & - & - & - & - & - & - & $\sqrt{ }$ & - & - & - & - & $\sqrt{ }$ \\
\hline 4 & \multicolumn{2}{|l|}{ Kehutanan } & - & $\sqrt{ }$ & - & $\sqrt{ }$ & - & - & $\sqrt{ }$ & $\sqrt{ }$ & - & $\sqrt{ }$ & $\sqrt{ }$ & $\sqrt{ }$ \\
\hline 5 & \multicolumn{2}{|l|}{ Perkebunan } & - & $\sqrt{ }$ & - & $\sqrt{ }$ & $\sqrt{ }$ & - & $\sqrt{ }$ & $\sqrt{ }$ & - & $\sqrt{ }$ & $\sqrt{ }$ & $\sqrt{ }$ \\
\hline 6 & \multicolumn{2}{|l|}{ Pertanian } & $\sqrt{ }$ & $\sqrt{ }$ & $\sqrt{ }$ & $\sqrt{ }$ & $\sqrt{ }$ & - & $\sqrt{ }$ & $\sqrt{ }$ & - & $\sqrt{ }$ & $\sqrt{ }$ & $\sqrt{ }$ \\
\hline 7 & \multicolumn{2}{|l|}{ Pertenakan } & - & $\sqrt{ }$ & - & - & $\sqrt{ }$ & - & $\sqrt{ }$ & $\sqrt{ }$ & - & $\sqrt{ }$ & - & $\sqrt{ }$ \\
\hline 8 & \multicolumn{2}{|l|}{ Perikanan } & $\sqrt{ }$ & $\sqrt{ }$ & - & - & $\sqrt{ }$ & - & - & $\sqrt{ }$ & - & $\sqrt{ }$ & - & $\sqrt{ }$ \\
\hline 9 & \multicolumn{2}{|l|}{ Pertambangan Umum } & $\sqrt{ }$ & $\sqrt{ }$ & $\sqrt{ }$ & $\sqrt{ }$ & $\sqrt{ }$ & - & $\sqrt{ }$ & $\sqrt{ }$ & - & $\sqrt{ }$ & $\sqrt{ }$ & $\sqrt{ }$ \\
\hline 10 & \multicolumn{2}{|l|}{ Pariwisata } & - & $\sqrt{ }$ & - & - & $\sqrt{ }$ & - & $\sqrt{ }$ & - & - & $\sqrt{ }$ & - & - \\
\hline 11 & \multicolumn{2}{|l|}{ Angkutan/Transportasi } & $\sqrt{ }$ & $\sqrt{ }$ & - & $\sqrt{ }$ & - & - & $\sqrt{ }$ & $\sqrt{ }$ & - & $\sqrt{ }$ & $\sqrt{ }$ & $\sqrt{ }$ \\
\hline 12 & \multicolumn{2}{|c|}{ Ekspor impor } & - & $\sqrt{ }$ & - & $\sqrt{ }$ & - & - & $\sqrt{ }$ & $\sqrt{ }$ & - & $\sqrt{ }$ & - & - \\
\hline 13 & \multicolumn{2}{|c|}{ Perdagangan umum dan jasa } & $\sqrt{ }$ & $\sqrt{ }$ & $\sqrt{ }$ & - & - & - & $\sqrt{ }$ & $\sqrt{ }$ & - & $\sqrt{ }$ & $\sqrt{ }$ & $\sqrt{ }$ \\
\hline 14 & \multicolumn{2}{|c|}{ Properti (Perumahan/Real Estate) } & - & $\sqrt{ }$ & - & $\sqrt{ }$ & - & - & - & $\sqrt{ }$ & - & - & $\sqrt{ }$ & $\sqrt{ }$ \\
\hline 15 & \multicolumn{2}{|c|}{ SPBU/SPBG } & - & $\sqrt{ }$ & - & $\sqrt{ }$ & - & - & - & $\sqrt{ }$ & - & - & $\sqrt{ }$ & - \\
\hline 16 & \multicolumn{2}{|l|}{ General Suplier } & - & $\sqrt{ }$ & - & $\sqrt{ }$ & - & - & - & $\sqrt{ }$ & - & - & $\sqrt{ }$ & - \\
\hline 17 & \multicolumn{2}{|c|}{ Telekomunikasi dan Informasi } & $\sqrt{ }$ & - & - & - & - & - & - & - & - & - & - & $\sqrt{ }$ \\
\hline 18 & \multicolumn{2}{|c|}{ Pengerahan tenaga kerja } & - & - & - & - & - & - & - & - & - & - & - & $\sqrt{ }$ \\
\hline 19 & \multicolumn{2}{|l|}{ Pertambangan Minyak } & $\sqrt{ }$ & - & - & - & - & - & - & - & - & - & - & - \\
\hline 20 & \multicolumn{2}{|l|}{ Gas dan Energi } & $\sqrt{ }$ & $\sqrt{ }$ & - & - & - & - & - & - & - & - & - & - \\
\hline 21 & \multicolumn{2}{|c|}{ Kontraktor/Jasa Konstruksi } & $\sqrt{ }$ & $\sqrt{ }$ & - & - & - & - & - & - & - & - & - & - \\
\hline 22 & Perhotelan & & - & $\sqrt{ }$ & - & - & - & - & - & - & - & - & - & - \\
\hline 23 & Travel Biro & & - & $\sqrt{ }$ & - & - & - & - & - & - & - & - & - & - \\
\hline 24 & Pelayaran & & - & $\sqrt{ }$ & - & - & - & - & - & - & - & - & - & - \\
\hline 25 & Restoran & & - & $\sqrt{ }$ & - & - & - & - & - & - & - & - & - & - \\
\hline 26 & Penggadaian & & - & $\sqrt{ }$ & - & - & - & - & - & - & - & - & - & - \\
\hline 26 & Perbankan/BPR & & - & - & - & $\sqrt{ }$ & $\sqrt{ }$ & - & - & - & - & - & - & - \\
\hline 27 & Pengelolaan Sumur Tua & & - & - & - & - & - & - & - & - & - & - & - & - \\
\hline 28 & Usaha lainnya & & $\sqrt{ }$ & - & $\sqrt{ }$ & $\sqrt{ }$ & $\sqrt{ }$ & - & $\sqrt{ }$ & $\sqrt{ }$ & $\sqrt{ }$ & $\sqrt{ }$ & $\sqrt{ }$ & $\sqrt{ }$ \\
\hline & & Jumlah & 11 & 20 & 5 & 12 & 8 & 1 & 12 & 14 & 1 & 11 & 11 & 14 \\
\hline PJ & $=$ Provinsi Jambi & MR & $=\mathrm{Me}$ & rangi & & & & & TB & & $=$ Tan & jjab B & arat & \\
\hline BG & $=$ Bungo & $\mathrm{KJ}$ & $=\mathrm{Kot}$ & a Jam & & & & & SR & & $=$ Sarc & olang & & \\
\hline SP & $=$ Sungai Penuh & MJ & $=\mathrm{Mu}$ & aro Ja & mbi & & & & ТВ0 & & $=\mathrm{Teb}$ & & & \\
\hline TT & $=$ Tanjab Timur & $\mathrm{BH}$ & $=$ Bat & anghe & & & & & $\mathrm{KR}$ & & $=$ Ker & & & \\
\hline
\end{tabular}

lapangan usaha BUMD tidak sesuai dengan tujuan pendirian BUMD yaitu melarang kegiatan-kegiatan usaha telah dapat dilaksanakan oleh sektor swasta dan koperasi. Misalnya, usaha Stasiun Pengelolaan Bahan Bakar Umum/Gas (SPBU/SPBG) pada BUMD Bungo, Tanjabtim, Tanjabar, dan Tebo. Analisis data juga menunjukkan, pernah dicabut. 
hanya BUMD Kota Jambi yang memiliki bisnis utama yaitu mengusahakan pengadaan/penyediaan air minum sesuai dengan program pembangunan pemerintah daerah. Untuk BUMD Batanghari, walau bisnis utamanya jelas yaitu mengelola sumber daya sumur tua yang potensial yang belum dimanfaatkan, ${ }^{33}$ namun BUMD tersebut dalam praktiknya tidak beroperasi. ${ }^{34}$

\section{Implikasi terhadap Penyertaan Modal Daerah dan Kepemilikan BUMD}

UU Nomor 5 Tahun 1962 tentang Perusda tidak mengatur dasar hukum (bentuk hukum) yang digunakan dalam penyertaan modal kepada BUMD. Demikian pula dalam UU Pemda yang pernah berlaku, tidak mengatur dasar hukum (bentuk hukum) yang digunakan dalam penyertaan modal kepada BUMD. Berbeda dengan UU Perusda dan UU Pemda yang pernah berlaku, UU Pemda 2014 (Pasal 331 ayat 1 dan Pasal 333 ayat 2) mengatur bahwa Penyertaan Modal Daerah (PMD) baik dalam rangka pendirian maupun penambahan modal ke dalam BUMD, harus ditetapkan dengan perda. Namun demikian, UU Pemda 2014 tidak menjelaskan apa definisi dari PMD tersebut.

Dalam Pasal 1 angka 7 PP Nomor 44 Tahun 2005 tentang Tata Cara Penyertaan Modal Negara Pada BUMN dan Perseroan Terbatas disebutkan bahwa Penyertaan Modal Negara adalah pemisahan kekayaan negara dari Anggaran Belanja dan Pendapatan Negara atau penetapan cadangan perusahaan atau sumber lain untuk dijadikan sebagai modal BUMN dan/atau Perseroan Terbatas lainnya, dan dikelola secara korporasi. Ketentuan yang hampir sama terdapat dalam Pasal 1 angka 4 PP Nomor 27 Tahun 2014 tentang Pengelolaan BMN/BMD, yang menyebutkan Penyertaan Modal Pemerintah Pusat/Daerah adalah pengalihan kepemilikan Barang Milik Negara/ Daerah yang semula merupakan kekayaan yang tidak dipisahkan

33 Lihat Pasal 4 huruf a Perda Nomor 23/2008.

34 Lihat LHP BPK RI Nomor 36/LHP/XVIII.JMB/11/2016 tentang Laporan Hasil Pemeriksaan BPK atas Efektifitas Tata Kelola Pemerintah Daerah dalam Pembinaan BUMD TA 2011 sampai dengan TA 2016 Pada Pemerintah Provinsi Jambi, hlm. 43. 
menjadi kekayaan yang dipisahkan untuk diperhitungkan sebagai modal/saham negara atau daerah pada badan usaha milik negara, badan usaha milik daerah, atau badan hukum lainnya yang dimiliki negara. Berdasarkan pengertian tersebut, maka PMD sebenarnya adalah pengalihan kepemilikan baik berupa uang atau barang milik daerah yang semula merupakan kekayaan yang tidak dipisahkan menjadi kekayaan yang dipisahkan untuk diperhitungakan sebagai modal/saham negara/daerah pada BUMN atau BUMD atau badan hukum lainnya yang dimiliki oleh negara/daerah. Berdasarkan konsepsi tersebut, prinsip-prinsip hukum terhadap PMD kepada BUMD adalah:

1. PMD kepada BUMD harus ditetapkan dengan perda. PMD ini dapat berbentuk uang atau barang milik daerah. ${ }^{35}$

2. Dalam perda pendirian atau perda perubahan bentuk hukum BUMD harus dimuat besarnya PMD. ${ }^{36}$ Dengan demikian, apabila dalam pembentukan BUMD tidak tercantum besarnya PMD, maka perda tersebut tidak sesuai dengan UU Pemda 2014.

3. PMD kepada BUMD dapat ditambah, dikurangi, dijual kepada pihak lain, dan/atau dialihkan kepada BUMN dan/atau BUMD (Pasal 304 ayat 2).

4. Untuk BUMD Perumda, seluruh modalnya (100\%) harus dimiliki oleh satu daerah dan tidak terbagi atas saham. Dalam hal Perumda akan dimiliki oleh lebih dari satu daerah, Perumda harus merubah bentuk hukum menjadi Perseroda (Pasal 334).

5. Untuk BUMD Perseroda, modalnya terbagi atas saham yang seluruh atau paling sedikit $51 \%$ harus dimiliki oleh satu daerah (Pasal 339).

Agak berbeda dengan UU Pemda 2014, ketentuan Pasal 11 ayat (1) PP Nomor 54 Tahun 2017 menegaskan bahwa dalam perda pendi-

35 Dalam hal PMD berbentuk Barang Milik Daerah, maka BMD tersebut harus dinilai terlebih dahulu dalam bentuk uang sesuai riil pada saat BMD dijadikan PMD. Lihat Pasal 21 ayat (3) PP Nomor 54 Tahun 2017.

36 Hal ini sejalan dengan ketentuan Pasal 331 ayat (1) dan Pasal 332 ayat (2) yang menyebutkan bahwa "penyertaan modal daerah kepada BUMD ditetapkan dengan Perda,baik dalam rangka pembentukan BUMD maupun untuk penambahan modal BUMD". 
rian BUMD Perumda harus dicantumkan "besarnya modal dasar dan modal disetor". Modal disetor tersebut harus dipenuhi paling lambat dua tahun sejak berdiri (Pasal 22 ayat 3). Pertanyaannya, mengapa untuk BUMD Perumda digunakan istilah "modal dasar" dan "modal disetor"? Menurut penulis, penggunaan sebutan modal dasar dan modal disetor tersebut tidak sesuai dengan UU Pemda 2014 dan praktik yang berlaku. Pertama, modal dasar dan modal disetor adalah sebutan yang digunakan dalam perusahaan yang berbentuk PT (BUMD Perseroda). Menurut Sentosa Sembiring, yang dimaksud dengan "modal dasar" adalah modal yang disebutkan dalam Anggaran Dasar PT. Dalam UU PT disebutkan modal dasar perseroan terdiri atas seluruh nilai saham (Pasal 31). Selanjutnya dalam Pasal 32 UU PT, modal dasar perseroan paling sedikit lima puluh juta rupiah). Sementara yang dimaksud dengan "modal disetor" adalah modal yang benar-benar telah ada dalam kas perseroan. Modal ini disetor oleh para pemegang saham. Seluruh saham yang telah dikeluarkan harus disetor penuh pada saat pengesahan perseroan dengan bukti penyetoran yang sah. ${ }^{37}$ Kedua, dalam praktik, tidak pernah pemda menggunakan sebutan "modal dasar" atau "modal disetor" dalam perda pendirian BUMD Perumda maupun dalam perda penambahan PMD ke dalam Perumda. Sebutan yang digunakan hanyalah "Penyertaan Modal Daerah".

Bagaimanakah implikasi berlakunya UU Pemda 2014 bila dihubungkan dengan prinsip PMD dan kepemilikan BUMD di Provinsi Jambi? Berdasarkan analisis data, terdapat ketidaksesuaian dengan prinsip UU Pemda 2014, yaitu: pertama, dalam Perda Pendirian BUMD tidak mencantumkan besaran jumlah penyertaan modal daerah (6 Perda BUMD) ${ }^{38}$. Kedua, dasar hukum penambahan penyertaan modal tidak ditetapkan dengan perda tetapi dengan Keputusan $\mathrm{Bu}-$ pati (5 BUMD) $)^{39}$. Ketiga, modal BUMD Perumda berbentuk saham (2

37 Sentosa Sembiring, Hukum Perusahaan Tentang Perseroan Terbatas (Jakarta: Nuansa Aulia, cetakan ketiga, 2012), hlm. 12-13.

38 Sebagai contoh Perda Kabupaten Merangin Nomor 6 Tahun 2015 tentang Pembentukan BUMD. Dalam Pasal 11 disebutkan: "modal dasar Perseroan ditetapkan dalam suatu peraturan daerah".

39 Sebagai contoh Perda Kabupaten Muaro Jambi Nomor 36 Tahun 2003 
BUMD) ${ }^{40}$ Keempat, modal BUMD Perusda dapat dimiliki oleh Pihak (2 BUMD $)^{41}$. Kelima, jumlah penyertaan modal yang disertakan oleh pemda ke dalam BUMD sangat kecil atau tidak rasional (4 BUMD). ${ }^{42}$

\section{Implikasi terhadap Organ BUMD}

Berbeda dengan UU Perusda, UU Pemda 2014 (Pasal 335 ayat 1 dan Pasal 340 ayat 1 serta Pasal 343 ayat 1 huruf j) menetapkan prinsipprinsip baru dalam organ BUMD, yaitu adanya keharusan dalam BUMD memuat kelengkapan organ utama dan organ pendukung. Untuk organ utama BUMD Perumda, susunannya terdiri dari (a) kepala daerah yang mewakili pemerintah daerah dalam kepemilikan kekayaan daerah yang dipisahkan pada Perumda (KPM); (b) direksi; dan (c) dewan pengawas. Untuk BUMD Perseroda, susunannya terdiri dari (a) RUPS; (b) direksi; dan (c) dewan komisaris. Sedangkan organ pendukung yang wajib ada dalam BUMD menurut Pasal 79-87 PP Nomor 54 Tahun 2017 adalah: (a) Satuan Pengawas Intern (SPI) sebagai pendukung direksi yang bertanggung jawab kepada Dirut; (b) Komite Audit (KA) sebagai pendukung Dewas/Deris; (c) Komite lainnya.

Bagaimanakah implikasi berlakunya UU Pemda 2014 dan PP Nomor 54 Tahun 2017 bila dihubungkan prinsip keharusan adanya organ utama dan pendukung dalam BUMD? Berdasarkan analisis data, terdapat ketidaksesuaian, yaitu pertama, pengaturan organ

tentang Perusahaan Daerah Muaro Jambi. Dalam Pasal 5 ayat (6) disebutkan: "Penambahan modal dasar Perusahaan daerah akan disesuaikan kebutuhan dan perkembangan usaha dan ditetapkan dengan Keputusan Bupati”.

40 Sebagai contoh Perda Kabupaten Tanjab Barat Nomor 7 Tahun 2002 tentang Perusahaan Daerah Tebo Holding Company. Dalam Pasal 3 ayat (1) disebutkan: "Modal PD JBS terdiri dari kekayaan Daerah yang telah dipisahkan dan 'dapat berbentuk saham' dengan modal dasar Rp2.000.000.000.000”.

41 Sebagai contoh Perda Kabupaten Muaro Jambi Nomor 36 Tahun 2003. Dalam Pasal 6 ayat (5) disebutkan: "perusahaan dimungkinkan untuk menerima penyertaan modal pihak ketiga atas persetujuan Bupati”.

42 Sebagai contoh Perda Kabupaten Sarolangun Nomor 44 Tahun 2001tentang Pembentukan Perusahaan Daerah Serumpun Pseko. Dalam Pasal 2 ayat (1) disebutkan Pemda hanya menyertakan modal Daerah sebesar Rp100.000.000. 
utama BUMD: (a) sebagian besar belum mencantumkan $\mathrm{KDH}$ sebagai KPM pada BUMD Perumda (6 BUMD); (b) masih menggunakan sebutan "Badan Pengawas" yang sudah dihapus oleh UU Pemda 2014 (5 BUMD); (c) masih terdapat Perda yang belum mencantumkan susunan organ BUMD Perseroda (2 BUMD). Kedua, seluruh Perda BUMD yang dikaji (100\%) belum memiliki organ pendukung berupa SPI dan KA.

\section{Implikasi terhadap Masa Jabatan Direksi dan Dewas/Deris}

UU Pemda 2014 tidak mengatur masa jabatan Direksi dan masa jabatan Dewas/Deris. Masa jabatan akan diatur lebih lanjut dengan PP. Hal ini berbeda dengan UU Perusda, yang menetapkan masa jabatan Direksi selama 4 (empat) tahun. Namun UU Perusda tidak menetapkan masa jabatan Dewas/Deris. Berbagai peraturan perundang-undangan yang diterbitkan sebagai tindak lanjut UU Perusda menetapkan masa jabatan Dewas/Deris adalah selama 3 (tiga) tahun. ${ }^{43}$

Sebelum PP Nomor 54 Tahun 2017 terbit, kebijakan pemerintah pusat dalam rangka pelaksanaan UU Pemda 2014 menentukan masa jabatan direksi ditetapkan 5 (lima tahun) dan dapat diangkat kembali untuk satu kali masa jabatan. ${ }^{44}$ Kebijakan ini kemudian dipertegas dalam Pasal 61 PP Nomor 54 Tahun 2017. Namun berbeda dengan masa jabatan Direksi, Dewan Pengawas/Dewan Komisaris masa jabatannya ditetapkan empat tahun dan dapat diangkat kembali untuk satu kali masa jabatan (Pasal 42). ${ }^{45}$ Ketentuan masa jabatan Direksi

43 Lihat: Pasal 20 ayat (3) Kepmendagri Nomor 50/1999tentang Kepengurusan BUMD; Pasal 19 ayat (3) Permendagri Nomor 7 / 1998 tentang Kepengurusal PDAM; dan Pasal 21 ayat (1) Permendagi Nomor 2/2007 tentang Organ dan Kepegawaian PDAM.

44 Kebijakan Pemerintah Pusat tertuang dalam Keputusan Mendagri Nomor 188.34.9083 Tahun 2016 tentang Pembatalan Pasal 15 ayat (1) Perda Provinsi Jawa Timur Nomor 14/2012 tentang BUMD yang menyebutkan: "Masa jabatan direksi paling lama 4 (empat) tahun dan dapat diangkat lagi untuk masa jabatan berikutnya setelah memenuhi persyaratan”. Menurut Kemendagri, ketentuan ini bertentangan dengan Pasal 16 ayat (4) UU BUMN yang menyatakan masa jabatan anggota Direksi ditetapkan lima tahun dan dapat diangkat kembali untuk satu kali masa jabatan.

45 Ketentuan ini berbeda dengan masa jabatan Dewas/Deris pada BUMN 
atau Dewas/Deris tersebut harus ditetapkan di dalam Perda.

Bagaimanakah implikasi berlakunya UU Pemda 2014 dan PP Nomor 54 Tahun 2017 bila dihubungkan dengan pengaturan masa jabatan Direksi dan Dewas/Deris di Provinsi Jambi? Berdasarkan analisis data, terdapat pertentangan dengan UU Pemda 2014 dan kebijakan Pemerintah Pusat, yaitu, pertama, masa jabatan Direksi tidak ditetapkan selama lima tahun tetapi ada yang empat tahun (delapan BUMD) dan ada yang tiga tahun (dua BUMD).$^{46}$ Kedua, masa jabatan Direksi dan Dewas/ Deris tidak ditetapkan dalam Perda (dua BUMD) ${ }^{47}$

\section{Implikasi terhadap Campur Tangan DPRD dalam Operasional BUMD}

Dengan berlakunya UU Pemda 2014 (Pasal 96, Pasal 101, Pasal 141 dan Pasal 151), DPRD dilarang "campur tangan" dalam operasional BUMD. Konsisten dengan itu, Mendagri telah menerbitkan Keputusan Nomor 188.34-3597 Tahun 2016 tentang Pembatalan Beberapa Ketentuan dalam Perda Provinsi Kalsel Nomor 3 Tahun 2014 tentang Perubahan Bentuk Badan Hukum Perusda menjadi Perseroan Terbatas Bangun Banua. ${ }^{48}$

Bagaimanakah implikasi berlakunya UU Pemda 2014 dan kebijakan pemerintah pusat bila dihubungkan dengan larangan campur tangan DPRD dalam operasinal BUMD di Provinsi Jambi? Berdasarkan analisis data, terdapat banyak pertentangan dengan UU Pemda 2014 dan kebijakan pemerintah pusat, yaitu pertama, pengaturan

yang masa jabatannya sama dengan Direksi, yaitu ditetapkan selama lima tahun. Lihat Pasal 48 ayat (4) dan Pasal 57 ayat (4) UU BUMN.

46 Lihat Perda Kabupaten Tanjab Timur Nomor 9 Tahun 2013 dan Perda Kabupaten Batanghari Nomor 3 Tahun 2008.

47 Lihat Perda Provinsi Jambi Nomor 13 Tahun 2001 dan Perda Kabupaten Merangin Nomor 6 Tahun 2015.

48 Pasal-pasal yang dibatalkan adalah: Pasal 23 ayat (1) dan Pasal 24 ayat (2) yang menyebutkan penggabungan, peleburan, pengambilalihan, pembubaran, dan likuidasi Perseroan ditetapkan oleh RUPS dengan terlebih dahulu mendapat persetujuan DPRD. Menurut Mendagri, kedua ketentuan tersebut bertentangan dengan tugas dan fungsi DPRD yang diatur dalam Pasal 96 dan Pasal 101 ayat (1) UU Pemda 2014. 
pemilihan, pengangkatan dan pemberhentian Direksi dan Dewas/ Deris dengan persetujuan DPRD (3 BUMD) ${ }^{49}$. Kedua, pengaturan penentuan gaji/tunjangan Direksi dan Dewas/Derisserta pegawai atas persetujuan DPRD (1 BUMD).${ }^{50}$ Ketiga, pengaturan kerjasama pemanfataan aset BUMD dengan persetujuan DPRD (1 BUMD). ${ }^{51}$

\section{E. Kesimpulan}

Berdasarkan pembahasan pada bagian sebelumnya artikel ini menyimpulkan, pertama, implikasi yuridis pengaturan BUMD pasca berlakunya UU Pemda 2014 meliputi bentuk hukum dan penamaan BUMD; persyaratan pendirian dan kelayakan usaha BUMD; penyertaan modal daerah dan kepemilikan modal dalam BUMD; organ BUMD; masa jabatan Direksi dan Dewas/Deris; dan campur tangan DPRD dalam operasional BUMD. Kedua, belum ada satu pun Pemerintah Daerah di lingkungan Provinsi Jambi yang menindaklanjuti amanat Pasal 402 ayat (1) UU Pemda 2014 untuk menyesuaikan regulasi BUMD sesuai dengan prinsip-prinsip regulasi dalam UU Pemda 2014. Berdasarkan analisis terhadap 12 Perda yang menjadi objek kajian, sebagian besar Perda BUMD belum sesuai dan/atau bertentangan dengan UU Pemda 2014 dan kebijakan Pemerintah Pusat dalam hal: bentuk hukum dan penamaan BUMD; persyaratan pendirian dan kelayakan usaha BUMD; penyertaan modal daerah dan kepemilikan modal dalam BUMD; organ BUMD; masa jabatan Direksi dan Dewas/Deris; dan campur tangan DPRD dalam operasional BUMD.

49 Sebagai contoh Pasal 4 ayat (5) Perda Kabupaten Tanjab Barat Nomor 7 Tahun 2002 yang menyebutkan: "Direksi diangkat dan diberhentikan oleh Bupati Tanjung Jabung Barat 'dengan persetujuan DPRD’ dan calon diajukan oleh Bupati minimal tiga orang baik dari PNS maupun dari profesional/swasta".

50 Lihat Pasal 17 ayat (2) Perda Kabupaten Kerinci Nomor 2 Tahun 2003 yang menyebutkan: "Besarnya gaji Direksi ditetapkan oleh Kepala Daerah atas usul Badan Pengawas dengan 'persetujuan DPRD”'.

51 Lihat Pasal 4 ayat (3) Perda Provinsi Jambi Nomor 13 Tahun 2001 yang menyebutkan: "Kerjasama Perseroan sebagaimana dimaksud dalam ayat (2) pasal ini, sepanjang yang menggunakan aset Daerah dan membebani keuangan daerah, perlu mendapatkan persetujuan DPRD”. 


\section{Daftar Pustaka}

\section{Artikel/Buku/Laporan}

Afandi, Arif. "Pengelolaan BUMD Harus Profesional”. Majalah Kabupaten Report, 5, 1 (2015): 28-32.

Bako, Ronny Sautma Hotma. "Permasalahan Hukum atas Bentuk Badan Hukum pada Badan Usaha Milik Daerah”. Jurnal Kajian, 15, 4 (2010): 751-775.

Hareva, Mandala. "Pengelolaan BUMD/Perusahaan Daerah di Provinsi Sumatera Barat, Nusa Tenggara Barat, dan Kalimantan Selatan”. Jurnal Kajian, 11, 3 (2010): 1-25.

Kansil, Christine S.T. Hukum Perusahaan Indonesia (Aspek Hukum Dalam Ekonomi). Jakarta: Pradnya Paramita, 2010.

Kamaludin, Rustian. "Peran dan Pemberdayaan BUMD dalam Rangka Peningkatan Ekonomi Daerah. Majalalah Perencanaan Pembangunan, 23 (2001): 1-16.

Khopiatuziadah. "Landasan Hukum Pengelolaan Badan Usaha Milik Daerah: Antara Ada dan Tiada”. Jurnal Legislasi Indonesia, 11, 3 (2014): 221-232.

Kusumo, Dhimas Tetuko, Munawar Kholis, dan Sentot Sudarwanto. "Kajian Yuridis Bentuk Hukum Badan Usaha Milik Daerah (BUMD) di Bidang Perbankan Pasca Berlakunya Undang-Undang Nomor 23 Tahun 2014 tentang Pemerintahan Daerah". Jurnal Privat Law, 4, 1 (2016): 21-29.

Moenek, Reydonnyzar. "Problematika, Peluang, Tantangan dan Strategi Pengelolaan BUMD, BLUD dan BMD”. http:/keuda. kemendagri.go.id. Diakses 15/7/2017.

Mulhadi. Hukum Perusahaan, Bentuk-Bentuk Badan Usaha di Indonesia. Bogor: Ghalia Indonesia, 2010.

Resen, Made Gde Subha Karma. "Implikasi Yuridis Diundangkannya Undang-Undang Nomor 23 Tahun 2014 tentang Pemerintahan Daerah terhadap Pengaturan Badan Usaha Milik Daerah di Indonesia”. Jurnal Yustisia, 3, 3 (2014): 127-135.

Republik Indonesia, Badan Pemeriksa Keuangan. "Laporan Hasil Pemeriksaan BPK Nomor 36/LHP/XVIII.JMB/11/2016 tentang 
Efektifitas Tata Kelola Pemerintah Daerah dalam Pembinaan BUMD TA 2011- TA 2016 pada Pemerintah Provinsi Jambi”.

Republik Indonesia, Badan Pemeriksa Keuangan. "Laporan Hasil Pemeriksaan BPK Nomor 38/LHP/XVIII.JMB/11/2016 tentang Efektifitas Tata Kelola Pemerintah Daerah dalam Pembinaan BUMD TA 2011-TA 2016 pada Pemerintah Kabupaten Batanghari".

Republik Indonesia, Kementerian Dalam Negeri. “Daftar Perda/

Perkada dan Peraturan Menteri Dalam Negeri yang Dibatalkan/Direvisi”. Http://www.kemendagri.go.id/media/ filemanager/2016 /06/21/b/a/batal_perda21_juni_2016.pdf. Diakses 20/9/2017.

Sembiring, Sentosa. Hukum Perusahaan Tentang Perseroan Terbatas. Jakarta: Nuansa Aulia, cetakan ketiga, 2012.

Yasin, Mahmudin. "BUMN dan Perekonomian Nasional”. https:/ / www.slideshare.net/pssdm/bumn-dan-pembangunan-nasional-12-des-2013-finalnon-lam-piran. Diakses 10/9/2017.

\section{Peraturan dan Putusan Hukum}

Republik Indonesia, Kementerian Dalam Negeri. Keputusan Menteri Nomor 188.34.9083 Tahun 2016 tentang Pembatalan Pasal 15 ayat (1) Perda Provinsi Jawa Timur Nomor 14/2012 tentang BUMD.

Republik Indonesia, Mahkamah Konstitusi. Putusan Nomor 62/ PUU-XI/2013. 